\title{
Review
}

\section{Teachers of the people: Political education in Rousseau, Hegel, Tocqueville, and Mill}

\author{
Dana Richard Villa \\ University of Chicago Press, Chicago, 2017, 352 pp., \\ ISBN: 978-0226467498
}

Contemporary Political Theory (2019) 18, S159-S162. https://doi.org/10.1057/s41296018-0217-4; published online 25 April 2018

Dana Villa's last book is a captivating reflection on a question which, given the current rise of populism, has become more and more urgent: political education. Populists tend to obviate this question, by claiming that the people are naturally virtuous and, at the same time, conferring on the leaders a great amount of power, not only to lead the people, but also to form them. But liberals as well, as Villa shows, can get entangled in similar kinds of conundrums, namely in the 'problem or perplexity - writ into the very idea of an education to autonomy' (p. 8). This is, in effect, the main theoretical question the book explores, through a penetrating analysis of the views of four canonical theorists: Rousseau, Hegel, Tocqueville, and Mill. As liberals, all of them welcomed the crumbling of the ancien regime and the democratisation of political life. But, as Villa convincingly argues, they all ended up defending a paternalistic, top-down, conception of civic education; one in which the 'goal of adult civic autonomy' and 'the means to get there' stand in a strong tension (p. 277). Despite this conclusion, the book shows that we have much to learn from how these thinkers dealt with the problem posed by political inclusion of a mass of poorly educated and politically inexperienced individuals. In this sense, we can say that all of them had to cope with a paradox, first theorised by Rousseau, which is essential to democracy: how a can a politically unformed people create laws and institutions that can transform them into a political community based on freedom and equality? All four thinkers agreed that political education was the response. Since politics requires moral, intellectual, and practical skills, they argued that it was necessary not only to educate these new political actors but also to find the appropriate teachers, since the people are not able 'to educate themselves' (p. 9).

Rousseau is the first theorist Villa considers. The analysis focuses on a key tension in his thought: that between the normative supremacy of the general will and the assumption that the people are not naturally equipped for self-government. Rousseau thus saw political education as a process that has to be instigated from the

(c) 2018 Macmillan Publishers Ltd., part of Springer Nature. 1470-8914 Contemporary Political Theory Vol. 18, S3, S159-S162 www.palgrave.com/journals 
outside, or better, from above: it is an external figure, the 'great legislator', who is responsible for inculcating in the people public spiritedness and for creating the institutions necessary to promote civic behaviour. There is an evident paradox at the core of Rousseau's republicanism: the great legislator exerts a 'determining influence while simultaneously fostering the illusion of political ... autonomy' (p. 81). In effect, the formative process, so conceived, cannot but entail a level of violence: that employed by the artist to mould an inert material. Rousseau, Villa specifies, was pragmatic enough to understand that the level of complexity (or corruption, according to him) reached by modern societies made this pedagogical effort practically impossible (with the exceptions of the Corsicans and the Poles). Rousseau therefore cannot be associated to those tragic projects, such as Pol Pot's in Cambodia, which tried to 'wipe the slate clean' and create a new society (p. 83). Nonetheless, for Villa there is not much to be saved in Rousseau's rigid conception of political education, apart for the insight into the difficulty of reconciling the general will and private interests.

Hegel and Tocqueville had a more nuanced view of the relation between private and public interests. Their attention focused on how to employ the institutions and practices of modern capitalist societies to mediate them. Villa offers a portrait of Hegel that locates him in the liberal constitutionalist tradition. The modern state represents for Hegel the culmination of a long historical process, through which freedom came to actualise itself. The rationale of the modern state is the reconciliation, both at the practical and the ethical levels, of the universal with the individual. This occurs through a set of integrating institutions - the family, the different elements of civil societies (specifically, the three estates), and the political state - that gradually enlarge the individuals' spheres of allegiance, making them part of an ethical whole. Political education thus consists in learning to recognise oneself as part of such whole, by participating in its net of institutions and practices. But Villa underlines the evident conservatism of such a conception, which casts civic education only in terms of learning to become good and lawabiding members of a highly integrated and hierarchically ordered state, leaving a minimal space for more active political participation by ordinary citizens.

Tocqueville's conception of political education is more active. For him, America's rich and diversified associational world represented a powerful counterpoint to modern individualism and also a school for civic life. He believed that, in participating in this decentralised network of associations and local institutions, American citizens could learn to think and act politically and mediate their private interests with the general ones. But, as Villa stresses, such possibility crucially depends on a specific constellation of historical circumstances: the fact that the American citizens came to share a set of moral values and beliefs, including a similar religious background. Like Rousseau, indeed, Tocqueville believed that the real foundation of a political community is to be found in the moral character of its citizens. This is what provides stability and cohesion.

S160 (C) 2018 Macmillan Publishers Ltd., part of Springer Nature. 1470-8914 Contemporary Political Theory Vol. 18, S3, S159-S162 
Therefore, for him, it was the French elites' obligation to make the people a bit 'more American', by instilling in them a similar set of uniform values and beliefs. So, Villa concludes, Tocqueville's democratic view of political education as bottom-up learning by doing is counterbalanced by a paternalistic and conservative idea of political education, reduced to a moralising, elite-driven effort to indoctrinate the people.

Villa proceeds to reveal a significant tension also at the core of Mill's political thought. Mill is remembered for advancing 'one of the most vehement antipaternalist defences of individual liberty and social openness imaginable' (p. 233). But this position is accompanied by a quite illiberal preference for society to be governed by an elite of enlightened individuals, a sort of 'technocratic liberalism avant la lettre' as Villa labels it (p. 273). Mill was very concerned that the democratisation of societies could consign the most educated classes - an elite of 'eccentric', cultivated individuals - to the position of a permanent minority, preventing them from fulfilling their function of enlightening the rest of society. This is why he believed it necessary to protect, not only in word, but also institutionally (for instance, through an electoral system that gave more representation to the most educated classes), the dominance of these elites. The other side of Mill's celebrated stance against conformism, then, is a form of elitist paternalism that he adopted towards those he considered still politically immature: the uneducated classes in 'advanced nations' and, even more, the people of 'barbarian' societies.

To conclude, Villa has written an important book that puts in historical perspective and provides theoretical depth to a central topic. His reading of the four theorists is essentially Arendtian in character: a reading based on the idea that civic education is really democratic only if it respects the citizens' autonomy, avoiding the transformation of the educated/the uneducated divide into one between the rulers/the ruled, thus reducing education to indoctrination. Villa advocates for a more indirect form of education, a learning by doing, through practices such as keeping oneself informed, debating about public life, and participating in associations and networks. I find this line of argument quite appealing. But the book is interesting also for the important questions it leaves open. For instance, I think we could ask to what extent this kind of learning by doing can be developed in our hypercapitalist, spectatorial regimes, in which most citizens do not go much beyond a sceptically detached engagement with politics. Villa is not really concerned with this question, as he focuses on a different epoch. However, this question directly bears on his topic insofar as it invites us to reflect on what kind of skills we consider necessary for politics. Are the critical capacities that a citizenspectator can develop sufficient? Or should we ask also for more practical skills, which require a deeper involvement in politics? In this respect, I find Villa's characterisation of the republican ideal of political education as moralising (p. 7) a bit simplistic as the republican tradition took as essential a set of practical and

(C) 2018 Macmillan Publishers Ltd., part of Springer Nature. 1470-8914 Contemporary Political Theory Vol. 18, S3, S159-S162 S161 
interpretative skills that are necessary, not only for political action, but also for understanding political language. We can recall, for instance, the role rhetoric played in this tradition, or the fact that Rousseau considered Machiavelli's Prince a handbook for republicans, and Gramsci a blueprint for the political party. Moreover, if the critique of paternalism in political education is certainly important, we could ask: should we leave some space for that kind of indirect learning, defended by Mill for instance, which occurs when we are exposed to exemplary political leaders? Or is this kind of learning also a form of paternalism?

Giuseppe Ballacci

University of Minho, 4710-057 Braga, Portugal gballacci@ilch.uminho.pt 